Al Maal : Journal of Islamic Economics and Banking

http://jurnal.umt.ac.id/index.php/jieb

E-ISSN : $2580-3816$

Vol : 2 No. 1 Bulan Juli Tahun 2020

Hlm : $63-80$

DOI : $\quad 10.31000 /$ almaal.v2i1.2763

\title{
Systematic Literature Review (SLR): Kompetensi Sumber Daya Insani Bagi Perkembangan Perbankan Syariah Di Indonesia
}

\author{
Luluk Latifah $^{1 *}$, Iskandar Ritonga ${ }^{2}$ \\ 1,2Jurusan Ekonomi Syari'ah, Universitas Islam Negeri Sunan Ampel, Surabaya, Indonesia \\ *luluk.delula@gmail.com
}

\begin{abstract}
Human resources have an increasingly important role in achieving the objectives of a governmental, private, corporate organization, including sharia banking. This study aims to find out how the development of human resource competencies in Islamic banking in Indonesia is seen from the theoretical and practical order, and how the solution is solved. With the paradigm approach of Systematic Literature Review in journals that have been publicized from 2016 to 2020, the results show that the low level of competence of human resources in Islamic banking in Indonesia both at the theoretical and practical level. sharia. in Indonesia. The solutions provided are: 1) Recruitment, selection and placement of human resources properly adjusted to their skills 2) Pay close attention when recruiting DPS (Sharia Supervisory Board) must really be competent both in terms of sharia and finance. 3) Increasing the role of tertiary institutions especially Islamic tertiary institutions to provide competent human resources by taking into account the existing integrity of sharia banking and being advised by the government as policy maker. 4) Increase the competence of human resources by increasing theoretical and practical aspects. 5) The ability of human resources in modifying Islamic sharia products and understanding of sharia contracts.
\end{abstract}

Keywords: Systematic Literature Review; Competence; Human; Banking.

\section{ABSTRAK}

Sumber daya insani mempunyai peranan yang semakin penting dalam pencapaian tujuan suatu organisasi pemerintahan, swasta, perusahaan, termasuk perbankkan syariah. Penelitian ini bertujuan untuk mengetahui bagaimana perkembangan kompetensi sumber daya insani pada perbankan syariah di Indonesia dilihat dari tatanan teoritis maupun praktis, dan bagaimana solusi pemecahannya. Dengan pendekatan paradigma Sistematic Literatur Review pada jurnal yang sudah dipubikasikan sejak tahun 2016 sampai tahun 2020 maka didapatkan hasil bahwa masih rendahnya tingkat kompetensi sumber daya insani pada perbankan syariah di Indonesia baik pada tataran teoritis maupun praktis.Rendahnya kompetensi sumber daya insani ini menyebabkan lemahnya kinerja perbankan syariah. di Indonesia. Solusi yang diberikan adalah: 1) Melakukan rekruitmen, seleksi dan penempatan sumber daya insani dengan benar sisesuaikan dengan ketrampilanny 2) Memperhatikan betul saat merekrut DPS (Dewan Pengawas Syariah) harus benar-benar yang berkompeten baik dari sisi syariah maupun keuangan. 3) Meningkatkan peran perguruan tinggi terutama perguruan tinggi Islam untuk menyediakan sumber daya insani yang berkompeten dengan memperhatikan keutuhan yang ada pada perbankan syariah dan di saranai oleh pemerintah selaku pembuat kebijakan. 4) Meningkatkan kompetensi sumber daya insan dengan peningkatan aspek teoritis maupun praktis. 5) Kkemampuan sumber daya insani dalam memodifikasi produk-produk syariah Islam dan pemahaman tentang kontrak-kontrak syariah

Kata kunci : Sistematika Literatur Review; Kompetensi; Insani; Perbankan. 


\section{Pendahuluan}

Perbankan syariah di Indonesia masih terus berjuang mempertahankan eksistensinya dalam industri keuangan di Indonesia. Seiring dengan perkembangan perbankkan syariah terdapat permasalahan yang sering dihadapi salah satunya adalah masalah sumber daya insani (Manusia). Hal inilah yang membuat pergerakan industri perbankkan syariah di Indonesia masih melambat (Thalha Alhamid, 2019).

Bila dalam suatu organisasi mempunyai masalah yang berhubungan dengan manajemen sumber daya insani, maka akan mempengaruhi kinerja perkembangan organisasi tersebut, dalam dunia perbankan peran sumber daya insani sangat penting dan strategis, sehingga dibutuhkan sumber daya insani yang kompeten dan professional dalam hal praktek maupun teori

Pertumbuhan pesat perbankan syariah di Indonesia tidak diimbangi dengan sumber daya insani yang memadai, terutama sumber daya insan yang memiliki latar belakang pengetahuan dalam bidang perbankan syariah. Menurut Rusydiana dalam (Thalha Alhamid, 2019) salah satu faktor yang menjadi penghambat berkembangnya industri perbanakan syariah di Indonesia adalah belum memadainya smber daya manusia yang terdidik dan professional.

Faktor-faktor yang menjadi penghambat tersebut menurut (Sodiq, 2017) adalah lemahnya pemahaman praktisi bank syariah baik sisi pengembangan bisnis maupun sisi syariah, praktisi hanya bisa menjelaskan apa yang mereka tahu tetapi tidak bisa menjawab apa yang ditanyakan oleh nasabah dan belum memadainya sumber daya insan yang terdidik dan professional.

Systematic review merupakan metode penelitian yang mengulas kembali mengenai topik tertentu yang menekankan pada pertanyaan tunggal yang telah diidentifkasi secara sitematis, dinilai, diilih dan disimpulkan menurut kriteria yang telah ditetapkan sebelumnya berdasarkan bukti dari penelitian yang berkualitas yang relevan dengan pertanyaan penelitian. Systematic review merupakan metode penelitian yang sistematis dalam mengidentifikasi literature, eksplisit dalam pernyataan tujuan, bahan dan cara dan berkembang dalam metodologi penelitian serta kesimpulan.

Pendekatan systematic Literature review mempunyai keunggulan untuk mendapatkan temuan yang valid dan dapat diaplikasikan dari beberapa sumber penelitian sebelumnya pada suatu fenomena yang spesifik. Tujuan dari penelitian dengan menggunakan pendekatan systematic review ini adalah untuk mengetahui kompetensi sumber daya insane bagi perkembangan perbankan syariah di Indonesia.

\section{KAJIAN LITERATUR Sumber Daya Insani}

Manajemen sumber daya manusia adalah penggabungan antara kata atau konsep manajemen dan sumber daya manusia yang keduanya mempunyai arti yang berbeda. Definisi MSDM (manajemen sumber daya manusia) menurut para pakar dalam Rosidah (2009) adalah:

1) Moses N. Kiggundu (1989), "Human resource management is the development and utilization of personnel for the effective achievment of individual, or 
organizational, community, national, and international goals and objectives." MSDM adalah pengembangan dan pemanfaatan pegawai dalam rangka tercapainya tujuan dan sasaran individu, organisasi, masyarakat, bangsa dan internasionalsecara efektif.

2) Edwin B. Flippo: "MSDM adalah proses perencanaan, pengorganisasian, pengarahan, dan pengawasan kegiatan-kegiatan pengadaan, pengembangan, pemberian kompensasi, pengitegrasian, pemeliharaan dan pelepasan sumber daya manusia agar tercapai berbagai tujuan individu, organisasi dan masyarakat".

3) Tulus (1992), "MSDM adalah proses perencanaan, pengorganisasian, pengarahan, dan pengawasan atas pengadaan, pengembangan, pemberian kompensasi, pengintegrasian, pemeliharaan dan pemutusan hubungan kerjadengan maksud untuk membantu mencapai tujuan organisasi individu dan masyarakat.

Allah SWT berfirman dalam surat Al-Baqarah (2) : 30 yang artinya. "Ingatlah ketika Tuhanmu berfirman kepada para malaikat :"Sesungguhnya aku hendak menjadikan khalifah di muka bumi." Mereka berkata : "Mengapa Engkau hendak menjadikan (khalifah) di bumi itu orang yang akan membuat kerusakan padanya dan menumpahkan darah, padahal kami senantiasa bertasbih dengan memuji Engkau dan mensucikan Engkau?" Tuhan berfirman : "Sesungguhnya aku mengetaui apa yang tidak kamu ketahui."

Manajemen Sumber Daya Insani (MSDI) merupakan bidang dari manajemen umum. Karena sumber daya insani mempunyai peranan yang semakin penting dalam pencapaian tujuan perusahaan maka berbagai pengalaman dan hasil penelitian dalam bidang sumber daya insani dikumpulkan dan didata secara sistematis dalam manajemen sumber daya insani yang bertujuan me-manage atau mengelola sumber daya manusia. Hal ini sesuai dengan firman Allah SWT pada surat Ibrahim (14) : 19 yang artinya : "Tidakkah kamu perhatikan, bahwa sesungguhnya Allah telah menciptakan langit dan bumi dengan hak? Jika Dia menghendaki, niscaya Dia membinasakan kamu dan menggantimu dengan mahkluk yang baru."

Manusia merupakan insan yang diciptakan oleh Allah SWT sebagai khalifah dimuka bumi untuk beribadah kepada-Nya seperti yang tercantum dalam surat AlDzariyat (51) : 56 ." Dalam ayat ini jelas dikatakan bahwa Allah SWT tidaklah menciptakan Jin dan manusia melainkan untuk mengenal-Nya dan menyembah-Nya, hal ini dijelaskan juga dalam Hadits Qudsi yang diriwayatkan oleh Mujahid yang berbunyi : "Aku laksanakan perbendaharaan yang tersembunyi, lalu Aku ingin supaya diketahui, mka Kujadikanlah makhluk, maka dengan adanya ciptaan-Ku itulah mereka mengetahuiku."

\section{Perbankan Syariah}

Menurut Kashmir dalam Nilam Sari dan Abrrar Amri (2018) Perbankkan adalah setiap perusahaan yang bergerak di bidang perbankan, menghimpun dan menyalurkan dana, artinya kegiatan yang dilakukan oleh lembaga perbankkan selalu berkaitan dengan bidang perbankan, apakah kegiatannya hanya menghimpun atau hanya menyalurkan dana atau bahkan kedua-duanya yakni menghimpun dan menyalurkan dana.

Perbankan syariah mulai eksis di Indonesia saat dikeluarkan UU No.7 tahun 1992 tentang bank yang menerapkan konsep bagi hasil. Bank pertama yang beroperasi secara syariah saat itu adalah Bank Muamalat. Undang-undang perbankan syariah tersebut diperbaharui untuk lebih menyempurnakan dalam perjalanannya yaitu dengan 
UU No.10 Tahun 1998 sebagai amandemen dari UU No.7 Tahun 1992, kemudian pada tahun 2008 diperbaharui lagi dengan UU No.21 Tahun 2008 dan digunakan sebagai regulasi sampai saat ini.

Dari perjalanan regulasi terhadap bank syariah yang memang keberadaannya sangat dinantikan oleh masyarakat Indonesia yang menginginkan bank bebas dari riba (bunga), walaupun juga masih menjadi kontrovesi tentang bunga itu sendiri sehingga sampai detik ini sudah hampir 30 tahun keberadaan perbankan syariah di Indonesia masih belum berkembang dengan pesat. Walaupun saat krisis moneter terjadi pada tahun 1997 - 1998 ketika krus mata uang terjun bebas sehingga mengakibatkan kerugian besar-besaran pada industri keuangan Indonesia terutama perbankan yang banyak di merger justru bank syariah menunjukkan ketangguhannya dengan keuangan yang sehat dan tetap stabil.

Menurut OJK Syariah sampai tahun 2018 secara nasional pebankan syariah mempunyai jaringan sebanyak 1.868 BUS (Bank Umum Syariah), 347 UUS (Unit Usaha Syariah), dan 289 BPRS (Bank Pengkreditan Rakyat Syariah). Meskipun mempunyai jaringan cukup banyak namun secara spesifik jaringan kantor perbankan syariah masih sedikit tersebar di beberapa daerah khususnya di Indonesia bagian Timur.

\section{Metode Penelitian \\ Metode Review}

Penelitian ini menggunakan pendekatan Systematic Literature Review (SLR) dengan sumber data berasal dari literatur jurnal terindex yang telah ber-ISSN (International Standard Serial Number) secara elektronik yang telah dipublikasikan melalui internet dengan kode E-ISSN. Pengambilan data dilakukan melalui surfing internet dari google scholars. Populasi data penelitian adalah jurnal dengan fokus sumber daya insani pada perbankan syariah di Indonesia ada sebanyak 13 jurnal teridex dari berbagai publisher atau penerbit jurnal.

Systematic Literature Review (SLR) didefinisikan sebagai proses mengidentifikasi, menilai, dan menafsirkan semua bukti penelitian yang tersedia dengan tujuan untuk memberikan jawaban untuk pertanyaan penelitian tertentu (Kitchenham dan Charters 2007). Tinjauan pustaka ini telah dilakukan sebagai tinjauan pustaka sistematis berdasarkan pedoman asli yang diusulkan oleh Kitchenham dan Charters (2007). 
Skema 1. Langkah-Langkah Systematic Literature Review (SLR)

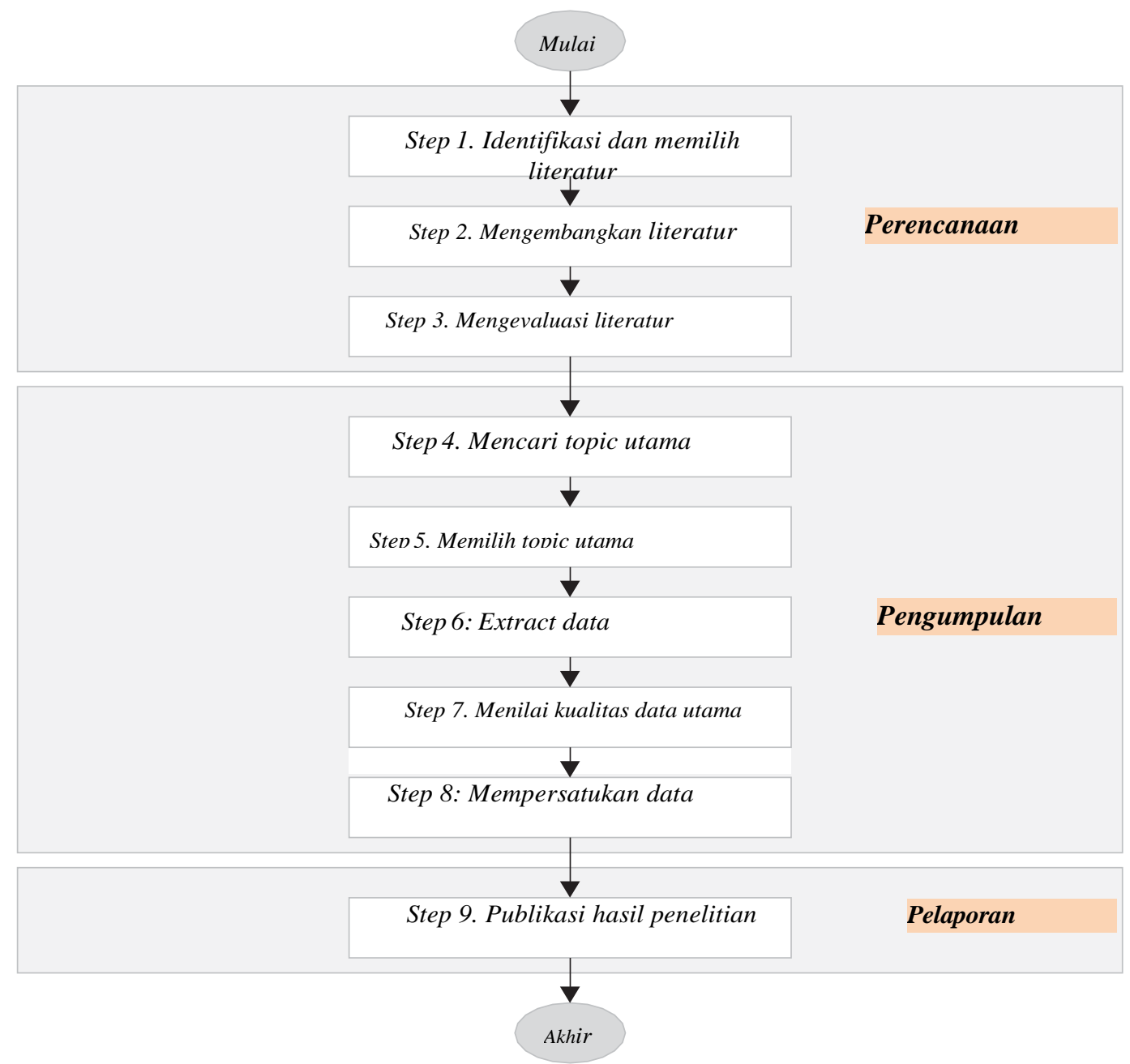

Pada Skema 1, Systematic Literature Review (SLR) dilakukan dalam tiga tahap: perencanaan, pelaksanaan dan pelaporan tinjauan literatur. Pada langkah pertama persyaratan untuk tinjauan sistematis diidentifikasi. Kemudian, tinjauan sistematis pada permasalahan perbankan syariah di Indonesia diidentifikasi dan ditinjau. Protokol tinjauan dirancang untuk mengarahkan pelaksanaan tinjauan dan mengurangi kemungkinan bias peneliti. Pada Langkah kedua, ini mendefinisikan pertanyaan penelitian, strategi pencarian, proses seleksi studi dengan kriteria inklusi dan eksklusi, penilaian kualitas, dan akhirnya proses ekstraksi dan sintesis data. Langkah ketiga adalah palaporan dengan menuliskan hasil penelitian berdasarkan literatur yang telah melalui proses langkah pertama dan kedua, kemudian membahasnya dalam hasil penelitian dan menyimpulkannya.

\section{Research Question (Pertanyaan Penelitian)}

Research question dibuat untuk menjaga agar systematic review yang dilakukan tetap fokus. Research question disusun dengan bantuan kriteria Populasi (Population), Intervensi (Intervention), Perbandingan (Comparison), Hasil (Outcomes), dan Konteks (Context) yang disinkat dengan PICOC (Kitchenham dan Charters, 2007). Tabel 1. menunjukkan struktur PICOC dari pertanyaan penelitian tentang Sistematic Literatur Review: Kompetensi sumber daya insani pada perkembangan perbankan di Indonesia. 
Tabel 1. Ringkasan PICOC Kompetensi Sumber Daya Insani

Pada Perkembangan Perbankan Di Indonesia

\begin{tabular}{cl}
\hline Population & Sumber daya manusia, sumber daya insani di perbankan syariah \\
\hline Intervention & $\begin{array}{l}\text { Rendahnya kualitas sumber daya insani di perbankan syariah, } \\
\text { kurangnya kompetensi sumber daya insani, lemahnya pengetahuan } \\
\text { sumber daya insani tentang perbankan syariah } \\
n / a\end{array}$ \\
Comparison & $\begin{array}{l}\text { Kompetensi baik kualitas, dan kuantitas sumber daya insani dalam } \\
\text { Outcomentingkatkan kinerja perbankan syariah }\end{array}$ \\
Context & $\begin{array}{l}\text { Kerjasama antar lembaga antara akademisi, pembuat keputusan, } \\
\text { dan lembaga perbankan syariah. }\end{array}$ \\
\hline
\end{tabular}
dibawah ini:

Research question yang dibangun pada penelitian ini seperti tertera pada tabel 2.

Tabel 2. Research Question pada Literatur Review

\begin{tabular}{|c|c|c|}
\hline$I D$ & Research Question & Motivation \\
\hline$R Q 1$ & $\begin{array}{l}\text { Jurnal mana yang merupakan } \\
\text { jurnal kompetensi sumber daya } \\
\text { insani perbankan Syariah di } \\
\text { Indonesia yang paling signifikan? }\end{array}$ & $\begin{array}{l}\text { Identifikasi jurnal yang paling } \\
\text { signifikan di bidang kmpetensi } \\
\text { sumber daya insani perbankan } \\
\text { Syariah di Indonesia. }\end{array}$ \\
\hline$R Q 2$ & $\begin{array}{l}\text { Siapa peneliti yang paling aktif } \\
\text { dan berpengaruh dalam } \\
\text { kmpetensi sumber daya insani } \\
\text { perbankan Syariah di Indonesia?. }\end{array}$ & $\begin{array}{l}\text { Identifikasi peneliti yang paling } \\
\text { aktif dan berpengaruh dalam } \\
\text { kompetensi sumber daya insani } \\
\text { perbankan Syariah di Indonesia. }\end{array}$ \\
\hline$R Q 3$ & $\begin{array}{l}\text { Apa topik dan tren penelitian } \\
\text { yang dipilih oleh para peneliti } \\
\text { tentang kompetensi sumber daya } \\
\text { insani perbankan Syariah di } \\
\text { Indonesia? }\end{array}$ & $\begin{array}{l}\text { Identifikasi topik dan tren } \\
\text { peneltian tentang kompetensi } \\
\text { sumber daya insani perbankan } \\
\text { Syariah di Indonesia. }\end{array}$ \\
\hline$R Q 4$ & $\begin{array}{l}\text { Metode apa yang paling sering } \\
\text { digunakan untuk penelitian } \\
\text { kompetensi sumber daya insani } \\
\text { perbankan Syariah di Indonesia. }\end{array}$ & $\begin{array}{l}\text { Identifikasi metode terbaik } \\
\text { dalam penelitian kompetensi } \\
\text { sumber daya insani perbankan } \\
\text { Syariah di Indonesia. }\end{array}$ \\
\hline$R Q 5$ & $\begin{array}{l}\text { Metode apa yang berkinerja } \\
\text { terbaik ketika digunakan untuk } \\
\text { kompetensi sumber daya insani } \\
\text { perbankan Syariah di Indonesia? }\end{array}$ & $\begin{array}{l}\text { Identifikasi metode terbaik } \\
\text { dalam kompetensi sumber daya } \\
\text { insani perbankan Syariah di } \\
\text { Indonesia. }\end{array}$ \\
\hline$R Q 6$ & $\begin{array}{l}\text { Metode apa yang diusulkan untuk } \\
\text { kompetensi sumber daya insani } \\
\text { perbankan Syariah di Indonesia? }\end{array}$ & $\begin{array}{l}\text { Identifikasi metode yang } \\
\text { diusulkan untuk kompetensi } \\
\text { sumber daya insani perbankan } \\
\text { Syariah di Indonesia. }\end{array}$ \\
\hline$R Q 7$ & $\begin{array}{l}\text { Kerangka kerja seperti apa yang } \\
\text { diusulkan untuk kompetensi } \\
\text { sumber daya insani perbankan } \\
\text { Syariah di Indonesia? }\end{array}$ & $\begin{array}{l}\text { Identifikasi kerangka kerja yang } \\
\text { paling sering digunakan untuk } \\
\text { kompetensi sumber daya insani } \\
\text { perbankan Syariah di Indonesia. }\end{array}$ \\
\hline
\end{tabular}

Dari tabel 2. diatas, metode dalam memprediksi kelemahan sumber daya insani perbankan Syariah di Indonesia untuk menjawab pertanyaan pada RQ4 sampai RQ7. Kemudian menentukan mana yang signifikan dan mana yang tidak. RQ4 sampai RQ7 ini adalah pertanyaan utama pada penelitian ini, sedangkan pertanyaan lainnya yaitu 
RQ1 sampai RQ3 digunakan untuk membantu dalam mengevaluasi konteks penelitiannya.

Skema 2. dibawah menunjukkan peta pikiran dasar tinjauan literature secara sistematis yang bertujuan untuk mengidentifikasi metode prediksi kelemahan sumber daya insani perbankan Syariah di Indonesia yang paling signifikan memprediksi kelemahan sumber daya insani perbankan Syariah di Indonesia. memprediksi kelemahan sumber daya insani perbankan Syariah di Indonesia yang paling signifikan

Skema 2. Peta Pikiran

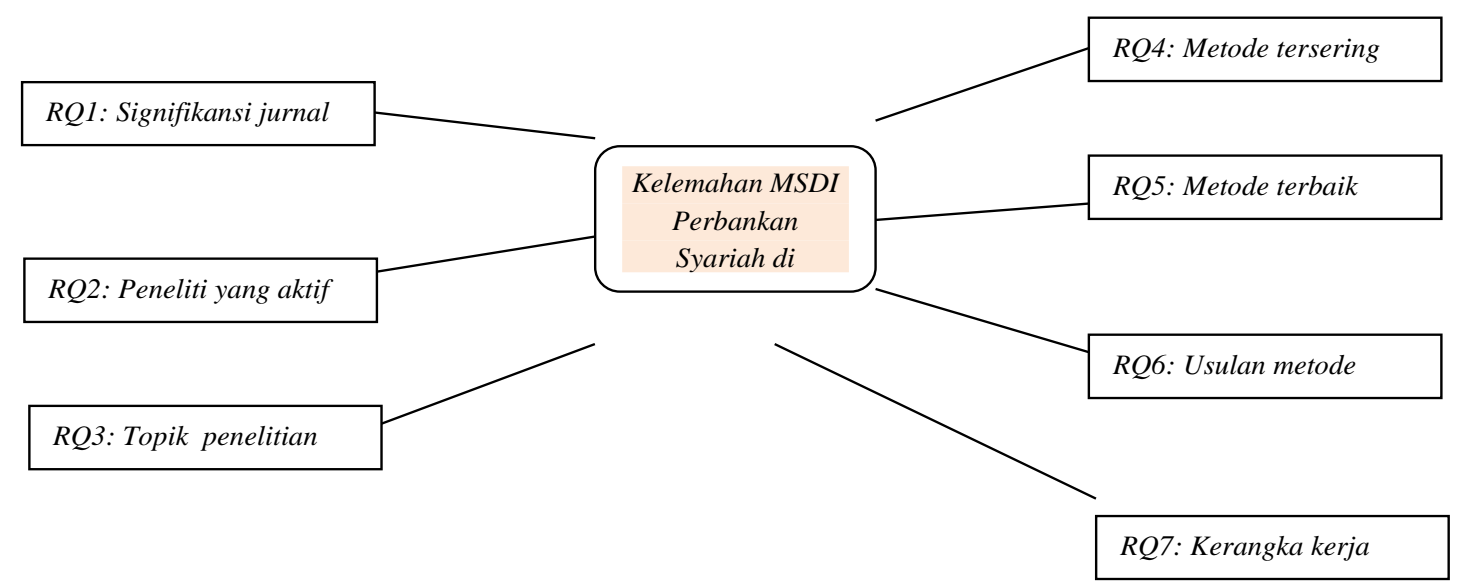

\section{Search Strategy (Strategi Pencarian)}

Strategi atau proses pencarian dalam Systematic Literature Review (SLR) yang dilakukan terdiri dari beberapa kegiatan, yaitu memilih perpustakaan digital, mendefinisikan string pencarian, melaksanakan pencarian, menyempurnakan string pencarian dan mengambil daftar awal studi utama dari perpustakaan digital yang cocok dengan string pencarian. Sebelum memulai pencarian, satu set database yang sesuai harus dipilih untuk meningkatkan kemungkinan menemukan artikel yang sangat relevan. Basis data literatur yang paling populer di lapangan dicari untuk memiliki set studi seluas mungkin. Perspektif yang luas diperlukan untuk cakupan literatur yang luas.

String pencarian dikembangkan sesuai dengan langkah-langkah berikut:

1) Identifikasi istilah pencarian dari PICOC, terutama dari Population and Intervention

2) Identifikasi istilah pencarian dari pertanyaan penelitian

3) Identifikasi istilah pencarian dalam judul, abstrak, dan kata kunci yang relevan

4) Identifikasi sinonim, ejaan alternatif, dan antonim dari istilah pencarian

5) Konstruksi string pencarian canggih menggunakan istilah pencarian pencarian yang teridentifikasi, AND Boolean dan OR

Dalam proses pencarian harus melakukan penyesuaian data pencarian dengan proses penyimpanan, karena penyesuaian data pencarian akan meningkatkan daftar studi yang tidak relevan. Data pencarian kemudian disesuaikan untuk memenuhi persyaratan 
spesifik dari setiap database. Basis data dicari berdasarkan judul, kata kunci, dan abstrak. Pencarian dibatasi oleh tahun publikasi: yaitu 10 tahun terakhir dari penulisan penelitian ini. Dua jenis publikasi yaitu makalah jurnal dan proses konferensi dimasukkan.

\section{Study Selection (Pemilihan studi)}

Kriteria inklusi dan eksklusi digunakan untuk memilih studi primer. Kriteria ini ditunjukkan pada Tabel 3 .

Tabel 3 Inklusi dan Ekslusi

\begin{tabular}{cl}
\hline & Studi dibidang akademik, perbankan syariah menggunakan set \\
& data skala besr dan kecil \\
& Studi yang membahas dan membandingkan tentang sumber daya \\
& insani pada perbankan syariah di Indonesia \\
Kriteria Inklusi & Untuk studi yang mempunyai referensi konferensi, hasil skripsi, \\
& thesiss, disertasi dan jurnal, maka hanya versi jurnal terindex \\
& ISSN yang akan disertakan \\
& Untuk publikasi duplikasi dari studi yang sama, hanya yang \\
& paling lengkap dan terbaru yang akan dimasukkan. \\
\hline \multirow{3}{*}{ Kriteria Ekslusi } & Studi tanpa ada validasi yang kuat \\
& Studi yang hanya membahas tentang sumber daya insani dan \\
& perbankan syariah di Indonesia \\
& Studi tidak ditulis selain bahasa Indonesia dan bahasa Inggris \\
\hline
\end{tabular}

\section{Data Extraction (Ektraksi Data)}

Studi utama yang dipilih diekstraksi kemudian dikumpulkan datanya yang berkontribusi untuk menjawab pertanyaan yang terkait dalam penelitian ini. Formulir ekstraksi data dirancang untuk mengumpulkan data dari studi utama yang diperlukan untuk menjawab pertanyaan penelitian. Properti diidentifikasi melalui pertanyaan penelitian dan analisis yang peneliti lakukan. Empat properti digunakan untuk menjawab pertanyaan penelitian yang ditunjukkan pada Tabel 4. Ekstraksi data dilakukan secara iteratif.

Tabel 4 Properti Ekstraksi Data Dipetakan ke Pertanyaan Penelitian

\begin{tabular}{ll}
\hline Properti & Research Quastion \\
\hline Identifikasi dan Publikasi & $R Q 1, R Q 2$ \\
$\begin{array}{l}\text { Trend an Topik Penelitian } \\
\text { Metode kompetensi sumber daya insani }\end{array}$ & $R Q 4, R Q 5, R Q 6$ \\
$\begin{array}{l}\text { perbankan Syariah di Indonesia } \\
\text { Kerangka kerja kompetensi sumber daya }\end{array}$ & $R Q 7$ \\
insani perbankan Syariah di Indonesia & \\
\hline
\end{tabular}

\section{Penilaian Kualitas Studi dan Sintesis Data}

Penilaian kualitas studi dapat digunakan untuk membimbing dalam interpretasi temuan sintesis dan untuk menentukan kekuatan kesimpulan yang diuraikan. Tujuan dari sintesis data adalah untuk mengumpulkan bukti dari studi yang dipilih untuk menjawab pertanyaan penelitian. Sepotong bukti mungkin memiliki kekuatan bukti kecil, tetapi agregasi banyak dari mereka dapat membuat poin lebih kuat. Data yang diekstraksi dalam tinjauan ini mencakup data kuantitatif dan data kualitatif. Berbagai 
strategi digunakan untuk mensintesis data yang diekstraksi berkaitan dengan berbagai jenis pertanyaan penelitian. Secara umum, metode sintesis naratif digunakan. Data ditabulasi dengan cara yang konsisten dengan pertanyaan. Beberapa alat visualisasi, termasuk diagram batang, diagram lingkaran, dan tabel juga digunakan untuk meningkatkan penyajian distribusi metode prediksi kelemahan sumber daya insani perbankan Syariah di Indonesia.

\section{Hasil dan Pembahasan}

\section{Publikasi Jurnal yang Signifikan}

Dalam ulasan Systematic Literatur Review (SLR) ini, ada 13 jurnal yang menganalisis kinerja sumber daya insani pada perbankan syariah di Indonesia. Setiap tahun terdapat jurnal yang membahas mengenai sumber daya insani pada perbankan syariah di Indonesia, bahkan terbanyak pada tahun 2018 beberapa jurnal dengan pendekatan kwalitatif maupun kwantitatif membahas mengenai sumber daya insane perbankan syariah di Indonesia ini, hanya satu jurnal yang membahas sejak tahun 2011, walaupun secara kriteria inklusi tidak bisa masuk namun secara ekslusi bisa digunakan dalam penelitian ini.

Tabel 5. Publikasi Jurnal Yang Signifikan

\begin{tabular}{|c|c|c|}
\hline No. & Nama Penerbit (Publikasi) & Kategori Dan Tahun \\
\hline 1. & Islamic Banking & 2019 \\
\hline 2. & $\begin{array}{l}\text { Al-Mashrafiyah (Jurnal Ekonomi, } \\
\text { Keuangan dan Perbankan Syariah) }\end{array}$ & 2018 \\
\hline 3. & $\begin{array}{l}\text { Fitrah: (Jurnal Kajian Ilmu-Ilmu } \\
\text { Keislaman) }\end{array}$ & e-ISSN 2442-6997 (2016) \\
\hline 4. & Jurnal Syarikah & e-ISSN: 2528-6935 (2018) \\
\hline 5. & $\begin{array}{l}\text { Jurnal Ekonomi Dan Perbankan } \\
\text { Syariah }\end{array}$ & e-ISSN: 2442-3076 (2018) \\
\hline 6 & Jrnal Syariah dan Hukum & 2018 \\
\hline 7. & $\begin{array}{l}\text { Ijtihad: (Jurnal Wacana Hukum Islam } \\
\text { dan Kemanusiaan) }\end{array}$ & 2018 \\
\hline 8. & Jurnal Ilmiah Ekonomi Islam & e-ISSN 2477-6157 (2016) \\
\hline 9. & Jurnal Ilmiah Mahasiswa & 2017 \\
\hline 10. & Cakrawala: Jurnal Studi Islam & e-ISSN: 2550-0880 (2018) \\
\hline 11. & $\begin{array}{l}\text { Al Masraf (Jurnal Lembaga Keuangan } \\
\text { dan Perbankan) }\end{array}$ & 2016 \\
\hline 12. & Jurnal Bisnis dan Manajemen & e-ISSN: 2461-1182 (2016) \\
\hline 13. & Al-Intaj & 2015 \\
\hline
\end{tabular}

\section{Peneliti Paling Aktif dan Berpengaruh}

Dari studi primer yang dipilih, peneliti yang berkontribusi sangat baik dan sangat aktif dalam bidang penelitian sumber daya insani pada perbankan syariah di Indonesia dapat diidentifikasi. Pada tabel 6 menunjukkan peneliti yang paling aktif dan berpengaruh di bidang sumber daya insani pada perbankan syariah di Indonesia. Dan yang paling berpengaruh adalah Trimulato yang paling banyak meneliti tentang sumber daya insane dan perbankan syariah. 
Grafik 1. Peneliti Dan Jumlah Karyanya

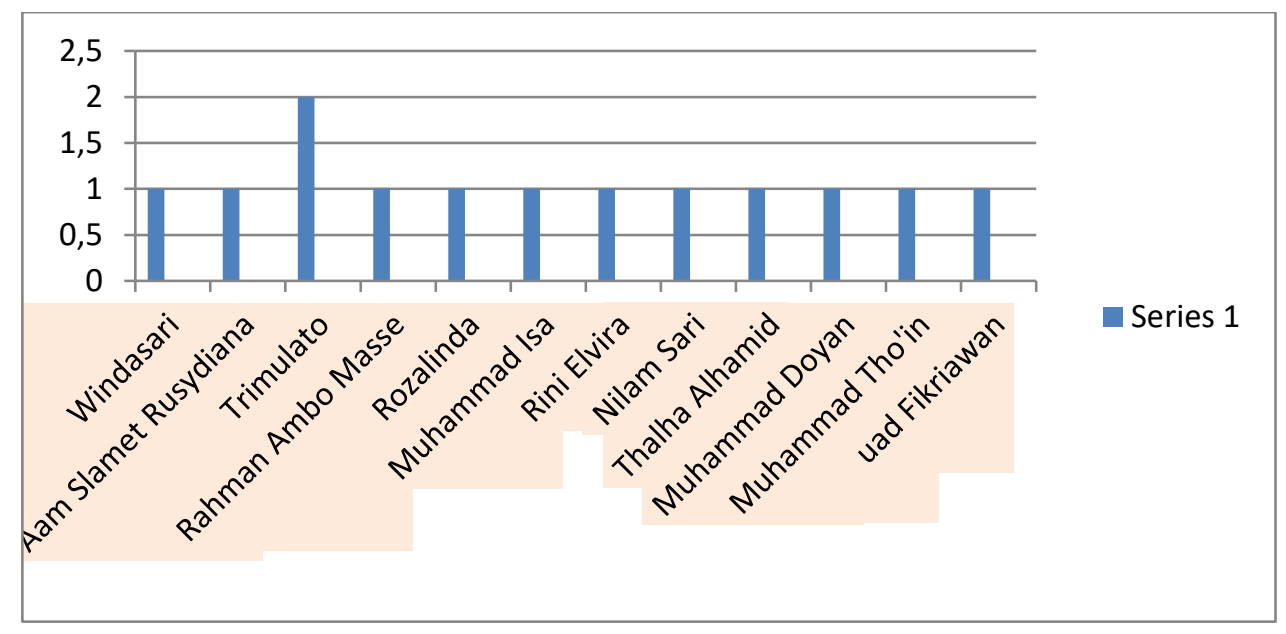

\section{Topik Penelitian}

Penelitian tentang kompetensi sumber daya insani pada perbankan syariah adalah topik penelitian yang signifikan di bidang manajemen sumber daya manusia, secara terperinci ada pada tabel 6. Analisis studi primer yang dipilih mengungkapkan bahwa penelitian kompetensi sumber daya insani pada perbankan syariah berfokus 5 topik yaitu:

1) Mengidentifikasi permasalahan sumber daya insani pada perbanakan syariah di Indonesia.

2) Mencari pernasalahan terbanyak yang dhadapi oleh sumber daya insani pada perbankan di Indonesia.

3) Menemukan penyebab terjadinya permasalahan sumber daya insani pada perbankan syariah di Indonesia.

4) Memilih solusi jawaban dari permasalahan sumber daya insani pada perbankan syariah di Indonesia.

5) Membuat kesimpulan solusi jawaban terlengkap dan terbaik dari semua penelitian tentang sumber daya insani pada perbankan syariah di Indonesia.

Tabel 6. Topik, Metode, Hasil Penelitian

\begin{tabular}{|c|c|c|c|c|}
\hline No. & Peneliti & Topik & Metode & Hasil \\
\hline 1. & $\begin{array}{l}\text { Windasari } \\
(2018)\end{array}$ & $\begin{array}{l}\text { Kualitas dan kinerja } \\
\text { sumber daya insani } \\
\text { pada lima lembaga } \\
\text { keuangan mikro } \\
\text { syariah }\end{array}$ & $\begin{array}{l}\text { Kualitatif } \\
\text { deskriptif, dg } \\
\text { observasi } \\
\text { dan FGD }\end{array}$ & $\begin{array}{l}\text { Beberapa LKMS memiliki } \\
\text { kualitas SDI yang baik. } \\
\text { Adanya sistem pengembangan } \\
\text { dan pelatihan SDI. }\end{array}$ \\
\hline 2. & $\begin{array}{l}\text { Aam Slamet } \\
\text { Rusydiana } \\
\text { (2016) }\end{array}$ & $\begin{array}{l}\text { Permasalahan yang } \\
\text { dihadapi } \text { oleh } \\
\text { institusi perbankan } \\
\text { syariah Indonesia }\end{array}$ & $\begin{array}{l}\text { Kualitatif } \\
\text { deskriptif }\end{array}$ & $\begin{array}{l}\text { Salah satu permasalahan yang } \\
\text { muncul dalam pengembangan } \\
\text { bank syariah di Indonesia } \\
\text { adalah SDM. }\end{array}$ \\
\hline 3. & $\begin{array}{l}\text { Trimulato } \\
(2018)\end{array}$ & $\begin{array}{lr}\text { Unit usaha } & \text { syariah } \\
\text { kekurangan } & \text { SDM } \\
\text { baik dari } & \text { segi }\end{array}$ & $\begin{array}{l}\text { Kualitatif } \\
\text { diskriptif } \\
\text { dengan studi }\end{array}$ & $\begin{array}{l}\text { Pola pengembangan SDI dengan } \\
\text { training, pelatihan, moral. } \\
\text { kecuali rekrutmen, seleksi dan }\end{array}$ \\
\hline
\end{tabular}


Systematic Literature Review (SLR): Kompetensi Sumber Daya Insani Bagi Perkembangan Perbankan Syariah Di Indonesia

kualitas maupun pustaka

kuantitas.

4. Trimulato (2018)
Pertumbuhan SDM Diskriptif di bank syariah dan kualitatif peran penting manajemen bagi SDI di bank syariah

5. Rahman Ambo Mase (2018)

Profesionalisme

sumber

manusia

Konsep MSDM pada perbankan syariah
Kalitatif
diskriptif
(2016)

7. Muhammad Isa (2016)
Pengelolaan SDI Kwalitatif pada perbankan diskriptif syariah

penempatan karena masih berada pada keputusan bank konvensional selaku induknya.

Adanya pertumbuhan SDM di bank syariah periode 2016 2017.

Manajemen mampu memenuhi SDM yang paham ilmu ekonomi dan ilmu syariah.

Salah satu cara yang dipakai oleh manajemen adalah Calestial manajemen yang terdiri dari zikir, piker dan mikir.

Kompetensi menjadi faktor terpenting dalam merekrut SDI dalam hal ini DPS.

Kompetensi tersebut adalah aspek penguasaan teori-teori fikih muamalah, membaca laporan keuangan dan hukum perikatan.

Pentingnya proses rekrutmen MSDM:

Seleksi Administrasi

Tes wawancara

Tes tertulis

Physicotes

Wawancara lanjutan $d g$

Direktur

Tes kesehatan

Peningkatan kualitas karyawan dengan pendidikan, pelatihan dan pengembangan MSDM sesuai rumpun jabatan

Pentingnya penyediaan SDI yang kompeten, handal dan professional dalam bidang ekonomi dan bisnis syariah.

Rekrutmen

Pengembangan

berkesinambungan

Kompensasi yang adil layak dan tepat waktu

Motivasi dengan suasana kekeluargaan saat masih aktif ataupun sudah pensiun

8. Rini Elvir Peran PTAI dalam Kawalitatif Membuka program studi (2015) mempersiapkan SDI diskriptif ekonomi Islam Merumuskan kurikulum yang tepat tentang ekonomi Islam dan akidah akhlak.

Penyediaan dana 
9. Nilam Sari Peran SDM dalam (2018)

10. Thalha

Alhamid

(2019)

11. Muhammad

Dayyan (2017)
Perkembangan

perbankan syariah dan Sumber daya Insani

Pengaruh SDI terhadap kinerja karyawan perbankan syariah pengembangan

Melakukan diklat relevan

Pengembangan peneltian dan

karya ilmiah.

Fasilitas dan sarana belajar yang memadai

Staf pengajar yang kompeten dan berkualitas

Program pendukung untuk onjob-training.

Mix method, Kualitas SDM mempengaruhi Kwantitatif kinerja karyawan, semakin kwalitatif tinggi kualitas maka semakin tinggi tingkat kinerja karyawan di bank syariah.

Kualitas SDM dapat ditingkatkan melalui:

Evaluasi kurikulum ekonomi syariah yang berkesinambungan di PT.

Pendirian program studi ekonomi syariah disesuaikan dengan kebutuhan pasar perbankan syariah.

PT kerjasama dengan BI melakukan pendidikan dan pelatihan ekonomi syariah bagi mahasiswa dan karyawan bank.

Pendidikan dan pelatihan tentang perbankan syariah.

Pengembangan yang bersinergi antara perbankan syariah, pemerintah dan PT.

Kwalitatif Rendahnya kualitas SDM diskriptif perbankan syariah disebabkan karena aspek kompetensi yang belum mumpuni baik dari segi teoritis maupun praktis.

Pengaruh yang positif signifikan antara SDI dengan kinerja karyawan.

Variabel SDI yang diteliti adalah pendidikan dan pelatihan dengan hasil:

Tingkat pendidikan tidak mempengaruhi kinerja karyawan

Pelatihan mempengaruhi

Kinerja karyawan

Membantah teori tentang apabila SDI rendah maka kualitas kinerjanya juga rendah dan begitupula sebaliknya. 


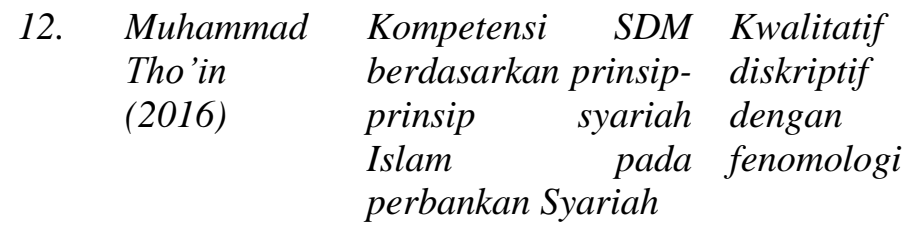

$\begin{array}{llll}\text { 13. Suad } & \text { Manajeman } & \text { Kwalitatif } \\ \text { Fikriawan } & \text { kompetensi SDM } & \text { diskriptif } \\ \text { (2018) } & \text { pada } & \text { perbankan } & \\ & \text { syariah renuju } & \\ & \text { Qualified } & \text { asean } & \\ & \text { bank } & & \end{array}$

Kompetensi yang harus ada pada SDM pada perbankan syariah berdasarkan prinsip syariah adalah:

Kemampuan dalam memodifikasi produk-produk perbankan yang dikombinasikan dengan prinsip syariah Islam yang meliputi:

tidak memberatkan.

menyedikitkan beban

penetapan hukum secara periodic.

memperhatikan kemaslahatan, persamaan dan keadilan.

Memahami kontrak-kontrak syariah.

Untuk menjawab masalah rendahnya kompetensi SDM, kurangnya ketersediaan SDM di bidang kesyariahan maka perlu adanya:

Manajemen kompetensi SDM yang ideal sesuai dengan prinsip-prinsip syariah.

Fungsionalisasi prinsip syariah dalam disain manajemen kompetensi SDM bank syariah.

Untuk mencapai no.1 dan 2, memadukan teori personal competency dan organizational competency dengan nilai-nilai syariah dengan manajeman langit yang mencakup workship, wealt dan warface.

Pada topik pertama yaitu mengidentifikasi permasalahan sumber daya insani pada perbanakan syariah di Indonesia, Windasari (2018) dan Trimulato (2018) menyoroti tentang kualitas dan kinerjanya, Rahman Ambo (2018) membahas tentang profesionalisme, Rozalinda (2016) mengulas tentang konsep sumber daya pada perbankan syariah. Rini Elvira (2015) meneliti mengeai sumber daya Insani yang harus disiapkan oleh Perguruan tinggi Islam sebagai lembaga pendidikan. Sedangkan Nilam Sari (2018) membahas mengenai peran sumber daya insani pada perbankan syariah, dan pengaruh dari sumber daya insani terhadap kinerja karyawan perbankan syariah dteliti oleh Muhamad Dayyan (2017). Muhammad Tho'in (2016) dan Suad Fikriawan (2018) meneliti tentang kompetensi sumber daya manusia berdasarkan prinsip-prinsip syariah.

Pembahasan topik kedua tentang pernasalahan terbanyak yang dhadapi oleh sumber daya insani pada perbankan di Indonesia adalah tentang kualitas, kuantitas dan kinerjanya yang dibahas oleh Windasari (2018) Trimulato (2018). Permasalahan yang lain adalah kompetensi sumber daya insane yang diteliti oleh Muhammad Tho'in (2016) dan Suad Fikriawan (2018). 
Topik ketiga menemukan penyebab terjadinya permasalahan sumber daya insani pada perbankan syariah di Indonesia adalah tentang lemahnya kinerja sumber daya insani yang disebabkan karena masalah rekutmen awalnya dan penempatan sumber daya yang kurang sesuai dengan jabatannya (Trimulato, 2018). Rozalinda (2016) juga mengatakan bahwa pentingnya proses rekrutmen sumber daya insani..

Topik keempat memilih solusi jawaban dari permasalahan sumber daya insani pada perbankan syariah di Indonesia. Windasari (2018) mengatakan perlu adanya sistem pengembangan dan pelatihan sumberdaya insani, sama dengan pendapat Trimulato (2018) selain itu dengan training, dan rekrutmen karyawan. Solusi rekrutmen ini juga dikemukakan oleh Rozalinda (2016) dengan tahapan-tahapannya seperti seleksi administrasi, tes wawancara, tes tertulis, psycotes, tes kesehatan dan wawancara akhir degan direktur. Trimulato (2018) dengan jurnal berbeda namun topiknya masih sama tentang sumber daya insani juga menjawab permasalahan sumber daya insani ini dengan pemenuhan sumber daya manusia yang paham ilmu-ilmu ekonomi dan ilmu syariah dengan cara menerapkan manajemen Calestial yang terdiri dari zikir, piker dam mikir. Suad Fikriawan (2018) Untuk menjawab masalah rendahnya kompetensi SDM, kurangnya ketersediaan SDM di bidang kesyariahan maka perlu adanya manajemen kompetensi SDM yang ideal sesuai dengan prinsip-prinsip syariah. dan fungsionalisasi prinsip syariah dalam disain manajemen kompetensi SDM bank syariah. dengan cara memadukan teori personal competency dan organizational competency dengan nilainilai syariah dengan manajeman langit yang mencakup workship, wealt dan warface.

Topik kelima yaitu solusi jawaban terlengkap dan terbaik dari semua penelitian tentang permasalahan lemahnya kompetensi sumber daya insani pada perbankan syariah di Indonesia adalah: dengan proses rekrutmen yang baik sesuai dengan konsepnya Rozalinda (2016) digabungkan dengan meningkatkan kompetensi sumber daya insani dengan cara meningkatkan kemampuan dan pengetahuan ilmu ekonomi dan penerapan ilmu syariah Islam dalam memahami kontrak-kontrak perbankan syariah yang disarankan oleh Muhammad Tho'in (2016) dan Nilam Sari (2018). Untuk mencapai tujuan tersebut maka perlu adanya manajemen langit yang diungkapkan oleh Suad Fikriawan (2018).

\section{Metode Penelitian}

Hampir semua peneliti menggunakan pendekatan kwalitatif diskriptif, baik dengan studi pustaka (library research), observasi, wawancara mendalam, atau fenomologi. Hanya ada beberapa peneliti yang menggunakan pendekatan kuantitatif yaitu Muhammad Dayyan (2017) dengan topik penelitiannya tentang uji pengaruh antara sumber daya insani dengan kinerja perbankan syariah. Selain itu ada juga dengan penggunaan metode gabungan antara kualitatif dan kuantitatif (mix method) yaitu Nilam Sari (2018).

Prosentase penggunaan metode penelitian ada pada grafik 1. dibawah ini. Metode yang terbaik yang seharusnya digunakan untuk meneliti tentang kompetensi sumber daya insane pada perbankan di Indonesia adalah metode gabungan antara kualitatif dan kuantitatif. mengapa demikian? karena dengan metode tersebut permasalahan yang ada yang akan dijawab dalam suatu penelitian bisa dijelaskan dengan berbagai pendekatan dengan menggunakan metode kualitatif sekaligus juga dapat dibuktikan secara statistic matematik dengan menggunakan metode kuantitatif, sehingga diperoleh hasil analisis yang lengkap. Metode kuantitatif digunakan untuk 
memperoleh hasil analisis yang terukur mengenai gambaran kompetensi sumber daya insane dan kinerjanya pada perbankan syariah di Indonesia, dan metode kualitatif digunakan untuk memperoleh informasi mengenai upaya peningkatan kompetensi sumber daya insane pada perbankan syariah di Indonesia.

Beberapa jurnal tentang sumber daya insan dan perbankan syariah yang direview ada beberapa yang hasilnya bertentangan setelah dilakukan uji statistik matematis yaitu dengan uji pengaruh antara variabel sumber daya insani dan variabel kinerja, seperti yang di teliti oleh Muhammad Doyan (2017) pada sebuah perbankan syariah, sumber daya insani tidak berpengaruh terhadap kinerjanya pada bank syariah tersebut, sementara perbankan syariah tersebut telah mempunyai dan selalu menerapkan SOP (Standart operasional Prosedur) untuk karyawannya baik yang lulusan mulai dari SMP sampai Perguruan tinggi.

Sementara Nilam Sari (2018) melakukan peneltian pada beberapa bank syariah dengan menggunakan metodologi gabungan antara kualitatif dan kuantitatif menghasilkan teori bahwa kualitas sumber daya insani sangat berpengaruh kuat pada kinerja karyawan pada perbankan syariah. Semakin tinggi kualitas sumber daya insane maka semakin tinggi pula kinerja karyawan pada perbankan syariah hal ini dibuktikan dengan analisis regresi dan analisis korelasi yang telah dilakukannya. Dan secara kualitatif Nilam Sari juga menyatakan bahwa ada hal-hal yang dilakukan untuk meningkatkan upaya kualitas sumber daya insani pada perbankan syariah berdasarkan wawancara yang mendalam kepada pimpinan beberapa perbankan tersebut yaitu:

1) Tentang memperluas dan memperdalam kurikulum Islam khususnya pada perbankan syariah di institusi Islam.

2) Membangun, mengembangkan dan memajukan instansi pendidikan ekonomi Islam.

3) Melaksanakan diklat/TOT Ekonomi Islam dengan sasaran untuk mendukung pertumbuhan melalui aspek demand dan suplay secara merata, mempererat pendanaan, mengintensifkan tugas pihak-pihak berwenang yang menjadiinisiator pertumbuhan ekonomi Islam, mengajak stakeholder (pemerintah, BI, Perguruan tinggi dan lembaga lainnya) perbankan syariah agar aktif sesuai dengan kemampuannya masing-masing dalam mengembangkan dan meningkatkan perbankan syariah.

Grafik 1. Prosentase Metode yang dipakai oleh peneliti

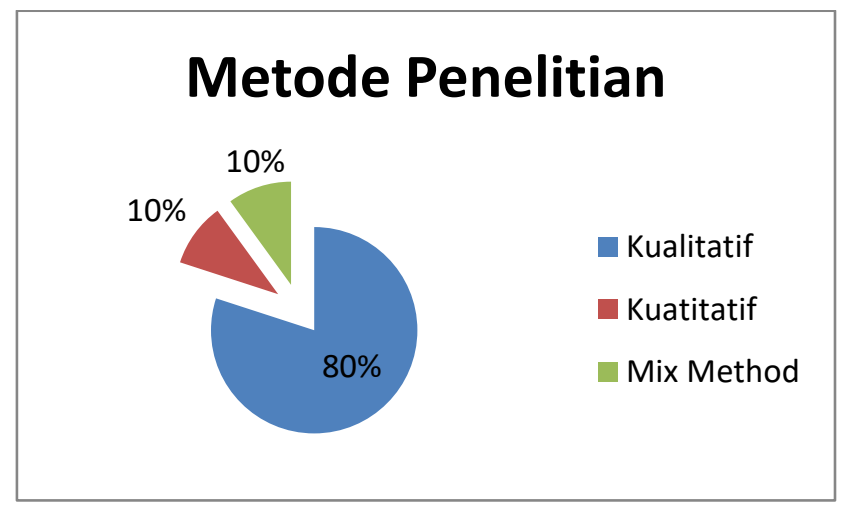


Muhammad Tho'in (2016) melakukan pendekatan kwalitatif diskriptif dengan fenomologi untuk menjelaskan tentang kompetensi yang harus ada pada sumber daya insani pada perbankan syariah. Kompetensi sumber daya insani ditingkatkan dengan cara memahami kontrak-kontrak syariah dan meningkatkan kemampuan sumber daya insani dalam memodifikasi produk-produk perbankan syariah yang mengkombinasi dengan prinsip-prinsip syariah meliputi dan tidak memberatkan nasabah, menyedikitkan beban, penetapan hukum secara periodic dan memperhatikan kemaslahatan, persamaan dan keadilan.

Suad Fikriawan (2018) dengan pendekatan diskriptif juga menjawab cara dalam mengatasi rendahnya kompetensi sumber daya insani pada perbankan syariah yaitu dengan menerapkan teori manajemen competency dan organizational teory yang dicetuskan oleh Spencer dan John W. Slocum dipadukan dengan konteks fungsionalisasinya yang harus berlandaskan pada nilai-nilai syariah yang dikemukakan oleh Irawan Arifin dengan manajemen langit yang mencakup tiga prinsip yaitu workship, wealth dan warfare.

\section{KESIMPULAN}

Hasil Sistematic Literatur Review dari semua penelitian yang terdapat pada jurnal yang sudah dipubikasikan sejak tahun 2016 sampai tahun 2020 menyatakan bahwa kompetensi sumber daya insani di Indonesia masih rendah baik pada tataran kualitas dan kuantitasnya serta kompetensi dari tatanan teoritis maupun praktis belum bisa menyeimbangkan dengan pergerakan perbankan syriah yang sudah ada di Indonesia sejak tahun 1992. Rendahnya kompetensi sumber daya insani ini menyebabkan lemahnya kinerja perbankan syariah.

Penyebab dari rendahnya kompetensi sumber daya insani pada perbankan syariah di Indonesia diantaranya karena: 1) Rekrutmen, seleksi dan penempatan pegawai belum sesuai dengan job desknya karena masih berdasarkan keputusan bank konvensional selaku induknya, hal ini terjadi bila perbankan syariah tersebut lahir dari bank konvensional yang berawal dari suatu UUS (Usaha Unit Syariah). 2) Penguasaan teori-teori fikih muamalah dan membaca laporan keuangan serta hukum perikatan yang kurang bagi DPS (Dewan pengawas Syariah) sehingga lemah dalam penerapan akadakad syariah. 3) Rendahnya peran stakeholder yang ada yaitu peran perguruan tinggi alam menyediakan kurikulum yang tepat, staf mengajar yang berkompeten dan berkualitas untuk kebutuhan perbankan syariah. 4) Aspek kompetensi yang belum mumpuni baik dari segi teoritis maupun praktis. 5) Belum adanya kemampuan dalam memodifikasi produk-produk perbankan yang dikombinasikan dengan prinsip syariah Islam.

Solusi yang diberikan untuk menjawab permasalahan rendahnya kompetensi sumber daya insani pada perbankan syariah di Indonesia diatas diantaranya adalah: 1) Melakukan rekruitmen, seleksi dan penempatan sumber daya insani dengan benar sisesuaikan dengan job desknya atau skillnya atau ketrampilanny sesuai dengan tahapan awal sampai akhir yaitu mulai dari Seleksi Administrasi, Tes wawancara, Tes tertulis, Physicotes, Wawancara lanjutan dengan Direktur, Tes kesehatan 2) Memperhatikan betul saat merekrut DPS (Dewan Pengawas Syariah) harus benar-benar yang berkompeten baik dari sisi syariah maupun keuangan. 3) Meningkatkan peran perguruan tinggi terutama perguruan tinggi Islam untuk menyediakan sumber daya insane yang 
berkompeten dengan memperhatikan keutuhan yang ada pada perbankan syariah dan di saranai oleh pemerintah selaku pembuat kebijakan. 4) Meningkatkan kompetensi sumber daya insane dengan peningkatan aspek teoritis maupun praktisnya. 5) Memberikan kemampuan sumber daya insani dalam memodifikasi produk-produk syariah Islam dan memberikan pemahaman tentang kontrak-kontrak syariah.

\section{REFERENSI}

Abdullah, Thamrin dan Francis Tantri, “.Bank dan Lembaga Keuangan.” Jakarta: PT RajaGrafindo Persada, 2013.

Ananta, Aris. “Ekonomi Sumber Daya Manusia." Jakarta, Lembaga Demografi FE UI, 1990.

Dayyan, Muhammad dkk, "Pengaruh Sumber Daya Insani Terhadap Kinerja Karyawan Perbankan Syariah: Studi kasus pada BPRS Adeco Langsa," Jurnal Ilmiah Mahasiswa Vol. 1 (1), 2017

Effendi, Sofian. Sjafri Saiin. M. Alwi Dahlan. "Membangun Martabat Manusia." Jogjakarta, Gadjah Mada University Press, 1996

Elvira, Rini, Peran Perguruan Tinggi Ekonomi Islam Dalam Mempersiapkan Sumber Daya Manusia Syariah,” Al-Intaj Vol. 1(1), 2015

Fikriawan, Suadi, "Manajemen Kompetensi Sumber Daya Manusia Bank Syariah Berbasis Prinsip-Prinsip Syariah Menuju Qualified Asean Bank," AlMasrafiyah: Jurnal Ekonomi Keuangan dan Perbankan Syariah, Vol.02(1), 2018

Idri. Hadis Ekonomi : Ekonomi dalam Perspektif Hadis Nabi. Jakarta: Prenada Media Group, 2015

Isa, Muhammad, "Pengelolaan Sumber Daya Insani Dalam Memasarkan Produk Dan jasa Lembaga Keuangan Syariah," Fitrah: Jurnal Kajian Ilmu-ILmu Keislamana, Vol. 02 (2), 2016

Imaniyati, Neni Sri, "Perbankan Syariah : dalam Perspektif Hukum Ekonomi," Bandung: Mandar Maju, 2013.

Iskandar, "Metodologi Penelitian Kualitatif,” Jakarta: GP Press, 2009

Kamil, Sukron : “Ekonomi Islam, Kelembagaan, dan Konteks Keindonesiaan”. Jakarta. PT RajaGrafindo Persada. April 2016

Karim, Adiwarman Azhar, "Bank Islam : Analisis Fiqih dan Keuangan," .Jakarta: PT RajaGrafindo Persada, 2016.

Kitchenham et al, "Asystematic Review of Cross vs.Within Company Cost Estimation Studies, " IEEE Transaction on Software Engineering, 33 (5), 2007

Lexy J. Moleong, Metode Penelitian Kualitatif, Edisi Revisi, Bandung: Remaja Rosdakarya, Cet. XXI, 2005

Masse, Rahman Ambo, "Dewan Pengawas Syariah dan Profesionalisme Sumber Daya Manusia,” Diktum: Jurnal Syariah dan hukum, Vol. 16(2), 2018.

Robbins, Stephen. Timothy A. Judge. "Organizational Behavior” Perilaku Organisasi (terjemahan). Jakarta: Salemba Empat, 2008

Rosidah, Ambar Teguh Sulistiyani. "Manajemen Sumber Daya Manusia." Yogyakarta: Graha Ilmu 2009

Rozallinda, "Konsep Manajemen Sumber Daya Manusia: Implementasi Pada Industri Perbankan Syariah,” Al-Masraf: Jurnal Lembaga Keuangan dan Perbankan, Vol. 01 (1), 2016 
Luluk Latifah, \& Iskandar Ritonga

Rusydiana, Aam Slamet, "Analisis Masalah Pengembangan Perbankan Syariah Di Indonesia: Aplikasi Metode Analytic Network Process," Jurnal Bisnis dan Manajemen Vol.6 (2), 2016.

Rosidah, Ambar teguh Sulistiyani, "Manajemen Sumber Daya Manusia”. Yogyakarta, Graha Ilmu 2009

Sulbi, Mulyadi. “Ekonomi Sumber Daya Manusia.” Jakarta: PT RajaGrafindp Persada, 2003

Sanafiah Faisal, Penelitian Kualitatif: Dasar-Dasar dan Aplikasi, Malang: YA3 Malang, Cet. I, 1990.

Sari, Nilam dan Abrar Amri, "Peran Sumber Daya Manusia (SDM) Dalam Perkembangan Perbankan Syariah: Analisis Kualitas dan Kinerja Pegawai," Ijtihad: Jurnal WacanaHukum Islam dan Kemanusiaan, Vol. 18 (2), 2018.

Tho'in, Muhammad, "Kompete3nsi Sumber Daya Manusia Bank Syariah Berdasarkan Prinsip-Prinsip Syariah Islam: Studi Kasus Pada BNI Syariah Surakarta," Jurnal Ilmiah Ekonomi Islam, Vol. 02 (3), 2016.

Trimulato, Penerapan Pengembangan Sumber Daya Manusia Islami Pada Unit Usaha Syariah," Cakrawala: Jurnal Stidi Islam, Vol 13 (1), 2018

Trimulato, "Manajemen Sumber Daya Manusia Islam Bagi SDM di Bank Syariah," Iqtishadia: Jurnal Ekonomi dan Perbankan Syariah, Vol. 05(2), 2018

Windasari dan Paramita, "Analisis Kualitas Sumber Daya Insani Pada Lembaga Keuangan Mikro Syariah, ” Jurnal Syarikah, Vol. 04 (2), 2018

Yusanto, Muhammad Ismail. Muhammad Karebet Widjajakusuma. "Manajemen Strategi Perspektif Syariah.” Jakarta, Khairul Bayaan, 2003.

Zainal, Veithzal Rivai. Salim Basalamah, Natsir Muhammad. "Manajemen Sumber Daya Insani." Cara Tepat dan mudah dalam menerapkan manajemen sumber daya insani dalam perusahaan secara Islami. Jakarta, PT RajaGrafindo Persada, 2014 